Research article

\title{
Organochlorine exposures influence on breast cancer risk and survival according to estrogen receptor status: a Danish cohort- nested case-control study
}

\author{
Annette P Høyer*1, Torben Jørgensen ${ }^{2}$, Fritz Rank ${ }^{3}$ and \\ Philippe Grandjean ${ }^{4,5}$
}

\begin{abstract}
Address: ${ }^{1}$ The Copenhagen Center for Prospective Population Studies (affiliation) Harsdorffsvej 1B, 2tv, DK-1874 Frederiksberg C, Denmark, ${ }^{2}$ Centre for Preventive Medicine, KAS Glostrup, Medical Dept. C/F, Entrance 8, 7 th floor, Ndr. Ringvej, DK-260o Glostrup, Denmark, ${ }^{3}$ Dept. of Pathology, Rigshopitalet, the National University Hospital, Blegdamsvej 9, DK-210o Copenhagen Ø, Denmark, ${ }^{4}$ Institute of Community Health, Odense University, Winsløwparken 17, DK-5000, Denmark and 5 Department of Environmental Health and Neurology, Boston School of Medicinal and Public Health, MA, USA
\end{abstract}

E-mail: Annette P Høyer* - aph@post8.tele.dk; Torben Jørgensen - tojo@glostruphosp.kbhamt.dk; Fritz Rank - rho2869@rh.dk; Philippe Grandjean - pgrand@ health.sdu.dk

*Corresponding author

\begin{abstract}
Background: The relationship between breast cancer and organochlorine exposure is controversial and complex. As estrogen receptor positive and negative breast cancer may represent different entities of the disease, this study was undertaken to evaluate organochlorines influence on breast cancer risk and survival according to receptor status.
\end{abstract}

Methods: The background material stems from the Copenhagen City Heart Study (Denmark 1976-78). The breast cancer risk was investigated in a cohort nested case-control design including 161 cases and twice as many breast cancer free controls. The cases served as a cohort in the survival analysis. Serum organochlorine concentrations were determined by gaschromotography.

Results: The observed increased breast cancer risk associated with exposure to dieldrin derived from women who developed an estrogen receptor negative (ERN) tumor (Odds ratio [OR] I vs. IV quartile, $7.6,95 \%$ confidence interval $[95 \% \mathrm{Cl}]$ I.4-46.I, p-value for linear trend 0.01 ). Tumors in women with the highest dieldrin serum level were larger and more often spread at the time of diagnosis than ERP tumors. The risk of dying was for the remaining evaluated compounds higher among patients with ERP breast cancer when compared to those with ERN. In the highest quartile of polychlorinated biphenyls ( $\Sigma \mathrm{PCB}$ ) it was more than 2-fold increased (Relative risk [RR] I vs. IV quartile, $2.5,95 \% \mathrm{Cl}$ I.I-5.7), but no dose-response relation was apparent.

Conclusion: The results do not suggest that exposure to potential estrogenic organochlorines leads to development of an ERP breast cancer. A possible adverse effect on prognosis of hormoneresponsive breast cancers needs to be clarified. 


\section{Background}

Many organochlorines have become ubiquitous in the environment and in the human body due to their resistance to degradation and their high solubility in lipids, which leads to accumulation in adipose tissue. Some of these compounds are suspected of disrupting the endocrine system and thereby increasing the risk of hormonedependent disorders and diseases such as breast cancer [1-3]. Epidemiological studies indicate that total lifetime exposure to estrogen predict the risk of breast cancer $[4,5]$. Estrogen also plays an important role for the prognosis of breast cancer as treatment with the anti-estrogenic drug tamoxifen improves the survival of postmenopausal women with estrogen receptor positive (ERP) breast cancer [6]. Furthermore, estrogen stimulates proliferation of ERP breast cell lines and may therefor be associated with ERP human breast cancers only [7].

Previous studies of the potential effect of estrogenic organochlorines on breast cancer risk have yield inconsistent results [8-23] and only a few has taken into account estrogen receptor status (ER) $[16,17,19]$. In a small Canadian study women with ERP tumors, but not those with estrogen receptor negative (ERN) tumors, had a higher DDE and PCB body burden compared to women with benign breast disease [16]. An excess risk of developing an ERP breast cancer associated with exposure to certain PCB congener was also demonstrated in a study conducted in Sweden [19].

In the so far only study on breast cancer survival, an adverse effect of exposure to dieldrin was identified, but ER was not obtained at that stage [24].

It has been postulated that ERP and ERN are two different entities of breast cancer having different biological and etiological mechanisms. Thus, distinguishing between breast cancer which growth is dependent on estrogen and those which is not i.e. ERP and ERN tumors, may have implications for studying potential estrogenic organochlorines possible influence on breast cancer risk and survival. Presented in this paper are results of analysis on breast cancer risk and overall survival while accounting for ER of the primary tumors.

To avoid problems with multiple comparisons, the analyses were restricted to organochlorines with estrogenic properties or compounds that are indicators of previous exposure to estrogenic ones.

\section{Materiel and methods}

The background material constitutes the Copenhagen City Heart Study (CCHS), which in 1976-78 enrolled a random sample of 10,317 women living within 10 wards of the National University Hospital of Copenhagen, Denmark. This study was designed as a cohort-nested casecontrol study, where the case group consisted of 268 women between 25 and 80 years of age diagnosed with primary breast cancer between initiation of the CCHS and end of follow up in 1993. They were identified through computerized linkage to the Danish Cancer Registry using the unique 10-digit ID-number issued to each resident in Denmark. As controls, a random sample of 536 women matched on age, and vital statistics was selected from the remainder of the CCHS cohort. Information on lifestyle factors, reproductive history, and socioeconomic conditions was obtained through standardized questionnaires in connection with a physical examination, which included body weight, and non-fasting blood samples. The serum was analyzed for cholesterol, triglycerides, and the remaining volume frozen. After the 17 years of follow up stored serum was retrieved from $240(89.5 \%)$ cases and 477 (89.0\%) of the matched controls.

Information on vital statistics, date of death until July 31 1997, breast cancer characteristics, and adjuvant treatment, were achieved through linkage to the Civil Registration System, the Causes of Death Registry, and the nation-wide clinical breast cancer trial conducted by the Danish Breast Cancer Co-operative Group. The latter was also able to provide information on where each woman diagnosed with breast cancer was treated. This made it possible to contact the pathology departments where the tumor tissue had been reviewed. Paraffin embedded tumor tissue was requested for estrogen receptor status determination immunohistochemically by microwave antigen retrieval, a mouse monoclonal anti-estrogen receptor antibody ER1D5, and the streptavidinbiotin detection system [25]. The threshold for designation of estrogen receptor positivity was staining of $>=$ $10 \%$ of the cell nuclei in the specimen.

Breast cancer characteristics included tumor size, degree of spread, and stage of disease. Patients who were defined as having received adjuvant therapy with tamoxifen include those treated solely with tamoxifen, and those who had a combination therapy including tamoxifen.

The stored serum was analyzed for potential estrogenic organochlorine compounds and their metabolites by the U.S. Center of Disease Control and Prevention in Atlanta: Hexachlorobenzene (HCB), dieldrin, polychlorinated biphenyls ( $\Sigma$ PCB calculated as the sum of following congeners: IUPAC numbers $28,52,56,66,74,99,101,105$, 110, 118, 138, 146, 153, 156, 170, 172, 177, 178, 180, 183, $187,189,193,194,195,201,203$, and 206), and p,p'DDE. The analytical technique involves a two-stage sol- 
id-phase extraction and clean-up followed by dual-column gas-chromatographic separation and electron capture detection [26]. To test for quality, bovine serum was used to which three concentrations of 9 commercial analytes were added. With every batch of 10 samples one quality control and one reagent-blank sample was analyzed. All quality control results were compared with limits established in the laboratory. If a quality sample was not within control limits the samples in this batch were discarded. Only completely resolved chromatographic peaks area ratios were compared with a linear calibration curve generated by analysis of standards of 6 different concentrations in triplet. Recoveries were calculated by subtracting the background level in the blank serum from the level in the spiked serum and dividing by the original spike concentration. The detection limit for all analytes was based on two SD of the result from the lowest control samples over the course of the analysis. The detection limits on the evaluated compounds are: $\mathrm{HCB}$ $0.05 \mathrm{ng} / \mathrm{mL}$, dieldrin $0.15 \mathrm{ng} / \mathrm{mL}$, p,p'-DDE $0.41 \mathrm{ng} / \mathrm{mL}$, and varied for the PCB congeners from $0.13 \mathrm{ng} / \mathrm{mL}$ to $0.30 n g / \mathrm{mL}$. For lipid adjustment the total serum lipid concentration $(\mathrm{mg} / \mathrm{dl})$ was calculated as:

$2.27 \times$ cholesterol $(\mathrm{mg} / \mathrm{dl})+$ triglycerides $(\mathrm{mg} / \mathrm{dl})+$ 0.623 [27].

A total of 161 cases (67.1\%) and their matched controls (318 breast cancer free women) were eligible for analysis of breast cancer risk according to ER. The case group (161) served as a cohort in the survival analysis.

Organochlorine concentrations were categorized in four levels of exposure using quartiles as cut-points. Associations between organochlorine exposure and breast cancer risk were examined by conditional logistic regression. ERP and ERN tumors were analyzed separately. The Cox proportional hazard method was used to investigate tumor characteristics, and the influence of organochlorine exposure on over all breast cancer survival [28]. The proportional hazard assumption was checked by log (-log) plots from stratified analyses. All variables included in the analyses complied with the assumption. Odds ratios (OR), relative risks (RR), and 95\% confidence intervals (CI) were computed using SAS statistical software [29]. Body weight (kg, in quartiles), parity (o, 1, $\geq 2$ children), menopausal status (pre- and postmenopausal), hormone replacement therapy (never, ever), smoking (never, ever), alcohol consumption (never or hardly ever, sometimes each month, sometimes each week, every day), household income (<400oDKK, 4000-10000DKK, >1000oDKK per month before tax), and school education $(<7,7-10,>10$ years $)$ were included in the risk analysis. Tumor size (actual size in $\mathrm{mm}$, or $<50 \mathrm{~mm},>50 \mathrm{~mm}$ ) degree of spread (axillary lymph nodes with metastatic involvement: $0,>1$ nodes), and stage of disease (early stage: tumor size $<50 \mathrm{~mm}$ and degree of spread o nodes; advanced stage: all other cases) were included in the survival analyses as potential confounders. Backward step-wise procedures were used to evaluate the modifying effect of the potential confounders and other organochlorines. Only covariates that reached statistical significance, were allowed to remain in the model. Due to the observations with non-detectable organochlorine concentrations, a test for trend in risk and prognosis was done using quartiles of organochlorine concentrations. All performed tests of statistical significance were two sided with a level of significance on $5 \%$.

The study has been performed in accordance with the Helsinki Declaration and approved by the Scientific Ethical Committee serving Copenhagen and Frederiksberg Municipality (KF) 01-157/94. Computerized linkage between Danish registries was performed according to Danish legislation.

\section{Results}

The immunohistochemical estrogen receptor analysis showed that $72.0 \%$ (116 cases) had developed an ERP breast cancer and 28.0\% (45 cases) an ERN cancers. Table 1 shows the measured lipid adjusted serum organochlorine concentration among these breast cancer cases.

Table I: Lipid adjusted serum concentrations of organochlorines among breast cancer cases with available estrogen receptor status.

\begin{tabular}{|c|c|c|}
\hline Organochlorine & $\begin{array}{c}\text { Min - Max concentration } \\
(\mathrm{ppb})^{\mathrm{a}}\end{array}$ & $\begin{array}{c}\text { Median concentration } \\
(\mathrm{ppb})\end{array}$ \\
\hline $\mathrm{HCB}$ & $L O D^{b}-1,901.50$ & 269.75 \\
\hline Dieldrin & LOD - 345.69 & 28.30 \\
\hline$\Sigma \mathrm{PCB}$ & $|56.84-2,62| .2 \mid$ & I,076.04 \\
\hline$p, p^{\prime}-D D E$ & $|62.0|-5,072.56$ & $1,129.75$ \\
\hline
\end{tabular}

${ }^{a}$ Parts per billion; ${ }^{b}$ Detection limit

High body weight, nulliparity, and use of hormone replacement therapy were identified as overall breast cancer risk factors (data not shown) and were therefore included as covariates in the analyses of organochlorine compounds. The excess risk of breast cancer associated with high body weight and hormone replacement therapy after menopause derives from women who developed and ERN breast cancer, but was not statistical significant (table 2). 
Table 2: Breast cancer risk factors by estrogen receptor status.

\begin{tabular}{|c|c|c|c|c|}
\hline \multirow[b]{2}{*}{ Factor } & \multicolumn{2}{|c|}{ Estrogen receptor positive } & \multicolumn{2}{|c|}{ Estrogen receptor negative } \\
\hline & $\begin{array}{l}\text { Adjusted OR (95\% } \\
\mathrm{Cl})^{\mathrm{a}}\end{array}$ & $\mathrm{P}$ trend $^{\mathrm{b}}$ & $\begin{array}{l}\text { Adjusted OR (95\% } \\
\mathrm{Cl})\end{array}$ & $\mathrm{p}$ trend $^{\mathrm{b}}$ \\
\hline \multicolumn{5}{|c|}{ Weight $(\mathrm{kg})$ by quartile } \\
\hline$<58$ & 1.0 ref. $^{c}$ & & 1.0 & \\
\hline $58-64$ & $0.7(0.5-1.5)$ & & $1.3(0.5-3.6)$ & \\
\hline $65-71$ & I.I (0.7-1.8) & & $1.9(0.7-4.9)$ & \\
\hline$>71$ & $1.2(0.7-1.9)$ & $>0.20$ & $2.1(0.8-5.9)$ & 0.10 \\
\hline \multicolumn{5}{|c|}{ Number of full term pregnancies } \\
\hline 0 & 1.0 & & 1.0 & \\
\hline 1 & $1.0(0.6-1.6)$ & & $1.7(0.6-5.1)$ & \\
\hline$>1$ & $0.6(0.4-0.9)$ & 0.01 & $1.2(0.5-3.1)$ & $>0.20$ \\
\hline \multicolumn{5}{|c|}{ Hormone replacement-therapy } \\
\hline Never & 1.0 & & 1.0 & \\
\hline Ever & I.I (0.7-I.7) & & $1.8(0.8-4.1)$ & \\
\hline
\end{tabular}

a Odds ratio, $95 \%$ confidence interval, age-adjusted; ${ }^{b}$ two sided $\mathrm{p}$-value for linear trend in OR's, ${ }^{\mathrm{c}}$ reference category.

The median duration of follow up with regard to death of all causes was 7.2 years; a total of 125 breast cancer patients died.

The overall breast cancer survival was related to tumor size, degree of spread, and stage of disease (data not shown). These prognostic indicators were significantly associated with breast cancer tumors that were ERN (table 3).

Table 3: Over all breast cancer survival in relation to clinical characteristics and stage of disease by estrogen receptor status.

\begin{tabular}{|c|c|c|}
\hline Characteristic & $\begin{array}{l}\text { Estrogen receptor posi- } \\
\text { tive } \\
\text { Adjusted RR }(95 \% \mathrm{Cl})^{\mathrm{a}}\end{array}$ & $\begin{array}{l}\text { Estrogen receptor neg- } \\
\text { ative } \\
\text { Adjusted RR }(95 \% \mathrm{Cl})\end{array}$ \\
\hline \multicolumn{3}{|c|}{ Tumor size $(\mathrm{mm})$} \\
\hline$<50$ & 1.0 ref. $^{b}$ & 1.0 \\
\hline$\geq 50$ & $0.7(0.2-3.0)$ & $5.4(1.8-15.9)$ \\
\hline \multicolumn{3}{|c|}{ Metastatic lymph nodes } \\
\hline 0 & 1.0 & 1.0 \\
\hline$\geq 1$ & $1.6(0.9-2.7)$ & $4.6(1.7-12.3)$ \\
\hline \multicolumn{3}{|l|}{ Stage of disease } \\
\hline Early & 1.0 & 1.0 \\
\hline Advanced & $1.5(0.9-2.6)$ & $6.0(2.1-16.9)$ \\
\hline
\end{tabular}

\footnotetext{
${ }^{\text {a }}$ Relative risk of dying, $95 \%$ confidence interval, adjusted for age at diagnosis; ${ }^{b}$ reference category.
}

Women with the highest serum concentration of dieldrin had a more than seven-fold increased risk of developing an ERN breast cancer compared to women with the lowest concentration, and the risk increased in a stepwise fashion with increasing dieldrin exposure level. No association could be observed for the ERP tumors (table 4). The frequency of large tumors (size $>50 \mathrm{Om}$ ) at the highest dieldrin quartile exposure group was $27.3 \%$ (average size, $37 \mathrm{~mm}$ ) and $8.7 \%$ (average size, $27 \mathrm{~mm}$ ) for ERN and ERP tumors, respectively. The corresponding figures for spread of disease was $61.5 \%$ and $45.8 \%$.

For the remainder of the organochlorine compounds, ORs for the highest exposure level tended to be higher for women who developed an ERP breast cancer than those who had an ERN tumor, though none of the relationships reached statistical significance (table 4). In general, the risk of dying among women with the highest organochlorine exposure level was higher among women with ERP than ERN breast cancers, but the only statistical significant relationship was observed for $\Sigma$ PCB (table 5). A statistically significant inverse trend was seen for exposure to $\mathrm{HCB}$ and $\Sigma \mathrm{PCB}$ in women with ERN tumors. Exposure to dieldrin was associated with a significant increased risk of dying for women with ERP tumors in the second and third quartile compared to the first quartile. An approximately 2-fold not significant increased risk of dying among women in the highest dieldrin exposure level compared to the lowest was observed for both ERP and ERN tumors (table 5). Similar results were obtained in analyses on a subgroup of 80 cases, where it was possible to adjust for tamoxifen therapy (data not shown). 
Table 4: Risk of breast cancer in relation to serum concentrations of organochlorines in quartiles by estrogen receptor status.

\begin{tabular}{|c|c|c|c|c|c|c|c|}
\hline \multirow{2}{*}{\multicolumn{2}{|c|}{$\begin{array}{l}\text { Organochlorines } \\
\text { in quartiles }(\mathrm{ng} / \mathrm{mL})\end{array}$}} & \multicolumn{3}{|c|}{ Estrogen receptor positive } & \multicolumn{3}{|c|}{ Estrogen receptor negative } \\
\hline & & Cases/controls & Adjusted RR $(95 \% \mathrm{Cl})^{\mathrm{a}}$ & $\mathrm{p}$ trend $^{\mathrm{b}}$ & Cases/controls & Adjusted OR (95\% Cl) & $p$ trend \\
\hline \multicolumn{8}{|c|}{$\mathrm{HCB}$} \\
\hline 1 & $<206.50$ & $36 / 56$ & 1.0 ref. $^{c}$ & & $19 / 23$ & 1.0 & \\
\hline ॥ & $206.50-269.75$ & $20 / 55$ & I.I (0.6-1.8) & & $8 / 23$ & $0.5(0.2-1.4)$ & \\
\hline III & $269.75-335.75$ & $22 / 56$ & $1.0(0.6-1.7)$ & & $11 / 23$ & $0.8(0.3-2.2)$ & \\
\hline IV & $>335.75$ & $36 / 55$ & $1.2(0.7-2.1)$ & $>0.20$ & $6 / 23$ & $0.4(0.1-1.4)$ & $>0.20$ \\
\hline \multicolumn{8}{|c|}{ Dieldrin } \\
\hline 1 & $<12.0 \mid$ & $27 / 57$ & 1.0 & & $6 / 23$ & 1.0 & \\
\hline ॥ & $12.01-28.30$ & $28 / 56$ & $1.3(0.7-2,2)$ & & $5 / 23$ & I.2(0.3-5.4) & \\
\hline III & $28.30-57.11$ & $33 / 57$ & $1.5(0.8-2.7)$ & & $13 / 23$ & $4.9(0.9-28.3)$ & \\
\hline IV & $>57.11$ & $28 / 56$ & $1.4(0.8-2.5)$ & $>0.20$ & $20 / 23$ & $7.6(1.3-46.1)$ & 0.01 \\
\hline \multicolumn{8}{|c|}{$\Sigma \mathrm{PCB}$} \\
\hline I & $<8 \mid 1.11$ & $36 / 57$ & 1.0 & & $14 / 23$ & 1.0 & \\
\hline ॥ & $811.11-1076.04$ & $24 / 56$ & I.I (0.6-I.7) & & $11 / 23$ & I.0 (0.4-2.7) & \\
\hline III & $1076.04-1405.73$ & $20 / 57$ & $0.7(0.4-1.2)$ & & $11 / 23$ & $1.3(0.4-3.9)$ & \\
\hline IV & $>1405.73$ & $36 / 56$ & $1.3(0.8-2.2)$ & $>0.20$ & $8 / 23$ & $0.8(0.3-2.6)$ & $>0.20$ \\
\hline \multicolumn{8}{|c|}{$p, p^{\prime}-D D E$} \\
\hline I & $<741.04$ & $33 / 57$ & 1.0 & & $14 / 23$ & 1.0 & \\
\hline II & $74 I .04-I \mid 29.75$ & $29 / 56$ & $0.7(0.4-1.2)$ & & $11 / 23$ & $0.9(0.3-2.5)$ & \\
\hline III & $1129.75-1688.85$ & $25 / 57$ & $0.8(0.5-1.3)$ & & $10 / 23$ & $0.7(0.2-2.0)$ & \\
\hline IV & $>1688.85$ & $29 / 56$ & $0.9(0.6-1.5)$ & $>0.20$ & $9 / 23$ & $0.6(0.2-1.7)$ & $>0.20$ \\
\hline
\end{tabular}

${ }^{a}$ Odds ratio, 95\% confidence interval, adjusted for age, weight, parity, and hormone replacement therapy; ${ }^{\mathrm{b}}$ two sided $\mathrm{p}$-value for linear trend in OR's; ' reference category. Cases with missing information on confounders were excluded.

Including other organochlorines than the particular one in question in the multivariate analysis did not have any modifying effect on the observed estimates on breast cancer risk and survival.

The cases on whom a tumor tissue specimen could not be obtained were older at the time of entrance into the CCHS ( $>60$ years of age, $42.3 \%$ vs. $19.1 \%$ ), older at the time of diagnosis ( $>71$ years of age at diagnosis, $32.1 \% \mathrm{vs.}$ 19.1\%), and more often nulliparous (nulliparity, 33.3\% vs. $24.1 \%$ ) compared to those with an available specimen.

\section{Discussion}

It has been postulated that ERP and ERN breast cancers represent different entities of the disease [7]. If this hypothesis is correct the risk factor profiles may differ between the two types of breast cancer, especially for hormone related factors as parity, hormone replacement therapy and body weight. The present study's results on these breast cancer risk factors according to ER are in accordance with previous epidemiological studies, which do not provide consistent evidence to conclude that development of ERP breast cancer is associated with exposure to estrogen related factors [30-36].
Only few prior studies have evaluated the role of potential estrogenic organochlorines relationship to breast cancer risk while accounting for estrogen receptor status of the primary tumors. An excess risk of developing ERP breast cancers associated with exposure to certain PCB congeners, and DDE have been demonstrated $[16,19]$. The present study could not confirm this. In fact, the previously reported excess risk observed with exposure to dieldrin derived from women who developed an ERN tumor [13]. However, it is still uncertain what happens in the preclinical phases of breast cancer development [37]. Low levels of available estrogen may stimulate estrogen receptor expression [38]. It is also possible that downregulation of the estrogen receptor gene to immunohisto-chemically undetectable levels may occur in some tumors due to high circulating levels of estrogens [38]. A breast cancer initiated as an ERP cancer could therefor change receptor status during the process of carcinogenesis prior to diagnosis. Thus ER status may merely represent different stages in disease progress. 
Table 5: Overall breast cancer survival in relation to serum concentrations of organochlorines by estrogen receptor status.

\begin{tabular}{|c|c|c|c|c|c|c|c|}
\hline \multirow{2}{*}{\multicolumn{2}{|c|}{$\begin{array}{l}\text { Organochlorines } \\
\text { in quartiles }(\mathrm{ng} / \mathrm{mL})\end{array}$}} & \multicolumn{3}{|c|}{ Estrogen receptor positive } & \multicolumn{3}{|c|}{ Estrogen receptor negative } \\
\hline & & Cases/control & Adjusted RR $(95 \% \mathrm{Cl})^{\mathrm{a}}$ & $p$ trend $^{b}$ & Cases/controls & Adjusted RR (95\% Cl) & $\mathrm{p}$ trend \\
\hline \multicolumn{8}{|c|}{$\mathrm{HCB}$} \\
\hline I & $<206.50$ & $13 / 15$ & 1.0 ref. $^{\mathrm{c}}$ & & $7 / 4$ & 1.0 & \\
\hline ॥ & $206.50-269.75$ & $15 / 14$ & $0.7(0.3-1.6)$ & & $8 / 3$ & $0.9(0.3-3.1)$ & \\
\hline III & $269.75-335.75$ & $17 / 12$ & I.I (0.5-2.4) & & $3 / 8$ & $0.2(0.0-1.2)$ & \\
\hline IV & $>335.75$ & $13 / 15$ & I.I $(0.5-2.5)$ & $>0.20$ & $4 / 7$ & $0.2(0.1-1.7)$ & 0.03 \\
\hline \multicolumn{8}{|c|}{ Dieldrin } \\
\hline I & $<12.01$ & $8 / 21$ & 1.0 & & $4 / 7$ & 1.0 & \\
\hline ॥ & $12.01-28.30$ & $17 / 12$ & $3.4(1.3-8.7)$ & & $3 / 8$ & $0.4(0.1-3.1)$ & \\
\hline III & $28.30-57.11$ & $17 / 12$ & $2.6(1.0-6.3)$ & & $7 / 4$ & $1.9(0.5-7.8)$ & \\
\hline IV & $>57.11$ & $17 / 12$ & $2.2(0.9-5.4)$ & $>0.20$ & $8 / 3$ & $1.8(0.3-5.5)$ & 0.06 \\
\hline \multicolumn{8}{|c|}{$\Sigma \mathrm{PCB}$} \\
\hline I & $<8|| .||$ & $14 / 15$ & 1.0 & & $6 / 5$ & 1.0 & \\
\hline ॥ & $811.11-1076.04$ & $15 / 14$ & $1.5(0.6-3.4)$ & & $7 / 4$ & $0.4(0.1-1.6)$ & \\
\hline III & 1076.04-| 405.73 & $13 / 16$ & $1.0(0.4-2.3)$ & & $5 / 6$ & $0.5(0.1-2.2)$ & \\
\hline IV & $>1405.73$ & $17 / 12$ & $2.5(1.1-5.7)$ & $>0.20$ & $4 / 7$ & $0.1(0.0-5.6)$ & 0.02 \\
\hline \multicolumn{8}{|c|}{$p, p^{\prime}-D D E$} \\
\hline i & $<741.04$ & $15 / 14$ & 1.0 & & $6 / 5$ & 1.0 & \\
\hline II & $74 I .04-I \mid 29.75$ & $13 / 16$ & $0.7(0.3-1.6)$ & & $4 / 7$ & $0.3(0.0-2.0)$ & \\
\hline III & $1129.75-1688.85$ & $17 / 12$ & $1.0(0.5-2.2)$ & & $5 / 6$ & $0.7(0.1-3.7)$ & \\
\hline IV & $>1688.85$ & $14 / 15$ & $1.0(0.5-2.1)$ & $>0.20$ & $7 / 4$ & $0.3(0.1-2.1)$ & $>0.20$ \\
\hline
\end{tabular}

\footnotetext{
${ }^{a}$ Relative risk of dying, $95 \%$ confidence interval, adjusted for age at diagnosis, metastatic lymph nodes, and tumor size; ${ }^{b}$ two sided $p$-value for linear

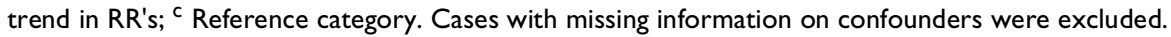

Large tumors are more frequently heterogeneous with respect to estrogen receptor expression than small tumors [39-42]. Consequently, a greater proportion of the large tumors will not exhibit estrogen reactivity at the time of diagnosis, although some part of it will be ERP. The tissue specimen obtained at the time of diagnosis may therefor not necessary reflect the original initiated breast cancer. These considerations may explain the present study's finding on dieldrin, as $27.3 \%$ of the ERN tumors among women in the highest exposure level had a diameter above $50 \mathrm{~mm}$, while the corresponding figure for the ERP tumors was only 8.7\%. Finally, it is possible that dieldrin is associated with a yet unidentified factor that modulates breast cancer risk.

Whether exposure to estrogen related risk factors or organochlorines with estrogenic potential results in development of an ERP breast cancer cannot be determined from current evidence, but deserves more attention in future larger studies.

In the only study evaluating the influence of organochlorines on overall survival of breast cancer, an adverse effect of dieldrin exposure was reported [24]. When the ER of the tumor was taken into account in the analysis of dieldrin, the relative risk of dying in the highest exposure level was elevated in both patients with ERP and ERN tumors, though not significantly. An adverse effect of dieldrin on survival of women with ERP tumors could be anticipated, as this compound is able to stimulate the growth of human estrogen-sensitive cells [2]. Another non-hormonal mechanism must lie behind the poorer prognosis of women with ERN tumors. Possibly, exposure to dieldrin may lead to development of a tumor with an increased inherent aggressiveness beyond what this study could take into account i.e. tumor size, degree of spread, and stage of disease. The significantly poorer prognosis observed for $\Sigma$ PCB in women with ERP tumors is in accordance with the hormonal potential of some PCB congeners [1].

The breast cancer's responsiveness to estrogen is exploited in endocrine surgery by removing the ovaries, and medically using drugs inhibiting the effects of estrogen on tumor cell growth. Worldwide results indicate that a $20 \%$ reduction in the five-year mortality is achieved by adjuvant therapy with tamoxifen in women over 50 years of age [6]. The use of tamoxifen has become more frequent and is not only reserved for postmenopausal patients or patients with ERP tumors, because a proportion 
of up to $10 \%$ of ERN tumors is found to respond to the therapy as well $[43,44]$. In this study tamoxifen was preferably administered to postmenopausal patients, but $26.3 \%$ of the patients who received this treatment had an ERN tumor. Tamoxifen competes with endogenous estrogen in binding to the receptor, and may therefore also block a possible effect of an estrogenic compound. However, adjustment for tamoxifen therapy in survival analyses on a sub-sample of the cohort (80 cases) did not substantially alter the observed results. The present study has several strengths. The participants were selected independently of risk of breast cancer and were followed for 17 years with regard to development of the disease. This time span allows the breast cancer to develop and takes into account the presumed long latency of this cancer. Furthermore, it is possible to give a longterm estimate for overall survival, as the median follow up with regard to death was 7.2 years. The substantial amount of information collected on the participants in the CCHS and the linkage to several relevant registries assured the ability to adjust for potential confounding, when evaluating both breast cancer risk and prognosis. The observed differences between cases eligible for and not eligible for assessing ER are unlikely to have affected the findings on breast cancer risk. Parity would be expected to be associated with lower organochlorine concentrations, as lactation is a main route by which these substances are excreted. Younger age would mean shorter duration of exposure and less accumulation. Thus, the study subjects included in the present study could have lower serum organochlorine concentrations and slightly lower risk of breast cancer than the CCHS cohort in general. Exclusion of cases diagnosed within 5 years of serum sampling did not affect the present results on risk and survival, and neither did mutual adjustment for organochlorine compounds.

The Danish unique 10-digit ID-number issued to all persons living in and entering the country (by birth or immigration) insure the completeness of the undertaken linkages. Since 1942, the Danish Cancer Registry has registered all cases of cancer occurring in the entire Danish population; the registry is regarded virtually complete [45]. DBCG has since 1976 been notified about new breast cancer cases by all Danish hospital departments [46].

The present study was not designed as a classical survival study and blood samples for assessment of organochlorine exposure was taken on average 8.7 years before the patients were diagnosed with breast cancer. Given the changes in organochlorine concentrations over time, the study only indirectly addressed the question whether estrogen or estrogenic compounds determined in 1976-78 may interfere with the prognosis of ERP tumors. On the other hand, breast cancer is estimated to take several (810) years to reach a clinical detectable size, which mean that assessment of organochlorine exposure at the time of diagnosis will not reflect the level at tumor initiation.

Even though this study included more breast cancer cases than most of the previous studies dealing with the organochlorine issue, it still has limited statistical power, especially in the analyses of ERN tumors.

\section{Conclusion}

The present study does not support the hypothesis that estrogen related risk factors or potential estrogenic organochlorines increase the risk of developing ERP tumors. In fact, it shows that exposure to dieldrin increases the risk of developing ERN tumors, which are larger and more often spread at the time of diagnosis. However, this finding should be interpreted with caution due to the limited number of ERN cases, so whether exposure to estrogenic organochlorine compounds affect the risk and prognosis of a hormone-responsive breast cancer needs to be clarified.

\section{Competing interests: None declared}

\section{Acknowledgement}

The authors thank Merete Appleyard, the Copenhagen City Heart Study, for competent help with identifying the cohort and locating the serum samples for chemical analysis and Dr John W Brock, Centers for Disease Control and Prevention in Atlanta, USA for performing the organochlorine analyses. This study was supported through the Boston University Superfund Basic Research Center by the National Institute of Environmental Health Sciences, (ES0738I), the Danish Medical Council, and the Danish Health Foundation.

\section{References}

I. Ahlborg UG, Lipworth L, Titus-Ernstoff L, Hsieh C-C, Hanberg A, Baron J, Trichopoulos D, Adami H-O: Organochlorine compounds in relation to breast cancer, endometrial cancer, and endometriosis: an assessment of the biological and epidemiological evidence. Crit Rev Toxicol 1995, 25:463-53 I

2. Soto AM, Chung KL, Sonnenschein C: The pesticides endosulfan, toxaphene, and dieldrin have estrogenic effects on human estrogen-sensitive cells. Environ Health Perspect 1994, 102:380-3

3. Bustos S, Denegri JC, Diaz F, Tchernitchin AN: p,p'-DDT is an estrogenic compound. Bull Environ Contam Toxicol 1988, I:91-8

4. Toniolo PG: Endogenous estrogens and breast cancer risk: the case for prospective cohort studies. Environ Health Perspect 1997 , I O(suppl 3):587-592

5. Dorgan JF, Longcope C, Stephenson HE Jr, Falk RT, Miller R, Franz C, Kahle L, Campbell WS, Tangrea JS, Schatzkin A: Serum sex hormone levels are related to breast cancer risk in postmenopausal women. Environ Health Perspect 1997, 105(suppl 3):583-585

6. Early Breast Cancer Trialists Collaborative Group: Systemic treatment of early breast cancer by hormonal, cytotoxic or immune therapy. Lancet 1992, 339:71-85

7. Zhu K, Bernard LJ, Levine RS, Williams SM: Estrogen receptor status of breast cancer: a marker of different stages of tumor or different entities of the disease. Medical Hypothesis 1997, 49:6975

8. Wolff MS, Toniolo PG, Lee EW, Rivera M, Dubin N: Blood levels of organochlorine residues and risk of breast cancer. J Natl Cancer Inst 1993, 85:648-5

9. Krieger N, Wolff MS, Hiatt RA, Rivera M, Vogelman J, Orentreich N: Breast cancer and serum organochlorines: $A$ prospective 
study among white, black, and Asian women. J Natl Cancer Inst 1994, 86:589-99

10. Van't Veer P, Lobbezoo IE, Matin-Moreno JM, Guallar E, Gómez-Aracena J, Kardinaal AFM, Kohlmeier, Martin BC, Strain JJ, Thamm M, et al: DDT (dicophane) and postmenopausal breast cancer in Europe:Case-control study. BMJ 1997, 3 I 5:8I-5

I I. Hunter DJ, Hankinson SE, Laden F, Graham SM, Colditz A, Manson JE, Willett WC, Speizer FE, Wolff MS: Plasma organochlorine levels and the risk of breast cancer. N Engl I Med I997, I 8: I253-8

12. Lopez-Carillo L, Blair A, Lopez-Cervantes M, Cebrian M, Rueda C, Reyes R, Mohar A, Bravo JL: Dichlorodiphenyl trichloroethane serum levels and breast cancer risk: A case-control study from Mexico. Cancer Res 1997, 57:3728-32

13. Høyer AP, Grandjean P, Jørgensen T, Brock JW, Hartvig HB: Organochlorine exposure and risk of breast cancer. Lancet 1998 , 352:1816-1820

14. Moysich KB, Ambrosone CB, Vena JE, Shields PG, Mendola P, Kostyniak P, Greizerstein H, Graham S, Marshall JR, Schisterman EF, et al: Environmental organochlorine exposure and postmenopausal breast cancer risk. Cancer, Epidemiology Biomarkers \& Prevention 1998, 7:181-88

I5. Dorgan JF, Brock JW, Rothman N, Needham LL, Miller R, Stephenson HE, Schussler N, Taylor PR: Serum organochlorine pesticides and $P B C s$ and breast cancer risk: results from a prospective analysis (USA). Cancer Causes Control 1999, I 0: I- I I

16. Dewailly E, Dodin S, Verreault R, Ayotte P, Sauvé L, Morin J, Brisson $\mathrm{J}$ : High organochlorine body burden in women with estrogen receptor-positive breast cancer. I Natl Cancer Inst 1994, 86:232-4

17. Helzlsour KJ, Alberg AJ, Huang H-Y, Hoffman SC, Strickland PT, Brock JW, Burse VW, Needham LL, Bell DA, Lavigne JA, et al: Serum concentrations of organochlorine compounds and the subsequent development of breast cancer. Cancer, Epidemiology, Biomarkers, \& Prevention 1999, 8:525-532

18. Güttes S, Failing K, Neumann K, Kleinstein J, Georgii S, Brunn H: Chloroganic pesticides and polychlorinated biphenyls in breast tissue of women with benign and malignant disease. Environ, Contam, and Toxicol 1998, 35:140-147

19. Liljegren G, Hardell L, Lindström G, Dahl P, Magnuson A: Case-control study on breast cancer and adipose tissue concentrations of congener specific polychlorinated biphenyls, DDE and hexachlorobenzene. Europ J Cancer Prev 1998, 7:135-140

20. Zheng T, Holford TR, Mayne ST, Tessari J, Owens SH, Zhang ZB, Dubrow R, Ward B, Carter D, Boyle P: Environmental exposure to hexachlorobenzene (HCB) and risk of female breast cancer in Connecticut. Cancer Epidemiology, Biomarkers \& Prevention 1999 , 8:407-4I I

21. Zheng T, Holford TR, Mayne ST, Ward B, Carter D, Owens PH, Dibrow R, Zahm SH, Boyle P, Archibeque S, et al: DDE and DDT in breast tissue and risk of female breast cancer. Am J Epidemiol 1999, 1 50:453-458

22. Aronson KJ, Miller AB, Woolcott CG, Sterns EE, McCready Likeey, LA DR, Fish EB, Hiraki GY, Holloway C, Ross T, et al: Breast adipose tissue concentrations of polychlorinated biphenyls and other organochlorines and breast cancer risk. Cancer, Epidemiology, Biomarkers \& Prevention 2000, 9:55-63

23. Demers A, Ayotte P, Brisson J, Dodin S, Robert J, Dewailly E: Risk and aggressiveness of breast cancer in relation to plasma organochlorine concentrations. Cancer, Epidemiology, Biomarkers \& Prevention 2000, 9:161-166

24. Høyer AP, Jørgensen T, Brock JW, Grandjean P: Organochlorine exposure and breast cancer survival. I Clin Epidemiol 2000, 53:323-330

25. Pertschuk LP, Feldman JG, Yong-Doo K, Braithwaite L, Schneider F, Braverman AS, Axiotis C: Estrogen receptor immunocytochemistry in paraffin embedded tissues with ER ID5 predicts breast cancer endocrine response more accurately than H222Sp $\gamma$ in frozen sections or cytosol-based ligand-binding assays. Cancer 1996, 77:2514-19

26. Brock JW, Burse VW, Ashley DL, Najam AR, Green VE, Korver MP, Powell MK, Hodge CC, Needham LL: An improved analysis for chlorinated pesticides and polychlorinated biphenyls (PCBs) in human and bovine sera using solid-phase extraction. I Anal Toxicol 1996, 20:528-36

27. Philipps DL, Pirkle JL, Burse VW, Bernert JT, Henderson O, Neddham LL: Chlorinated hydrocarbon levels in human serum: Effects of fasting and feeding. Arch Environ Contam Toxicol 1989, 18:495500

28. Cox DR: Regression models and life-tables (with discussion). JR Stat Soc 1972, 34:187-220

29. : SAS Technical Report P-2I7. SAS/STAT Software:The PHREG Procedure Version 6 SAS Institute, Cary, NC, USA I99|

30. Hildrith NG, Kelsey JL, Eisenfeld AJ, Li Volsi VA, Holford TR, Fisher DBL: Differences in breast cancer risk factors according to the estrogen receptor level of the tumor. I Natl Cancer Inst | 983, 70:1027-103|

31. Hislop TG, Coldman AJ, Elwood JM, Skippen DH, Kan L: Relationship between risk factors for breast cancer and hormonal status. Int J Epidemiol 1986469-476

32. Mc Tiernan A, Thomas DB, Johnson LK, Roseman D: Risk factors for estrogen receptor-rich and estrogen receptor-poor breast cancers. J Natl Cancer Inst 1986, 77:849-854

33. Stanford JL, Szkio M, Boring CC: A case-control study of breast cancer stratified by estrogen receptor status. Am J Epidemiol 1987, I 25:184-194

34. Cooper JA, Rohan TE, Horsfall DJ, Tilley WD: Risk factors for breast cancer by receptor status:a population-based casecontrol study. Br J Cancer 1989, 59:1 I 9-125

35. Kreiger N, King WD, Rosenberg L, Clarke EA, Palmer JR, Shapiro S: Steroid receptor status and the epidemiolgy of breast cancer. Ann.Epidemiol I991, I:513-523

36. Yoo KY, Tajima K, Miura S S: A hospital-based case-control study of breast-cancer risk factors by estrogen and progesterone receptor status. Cancer, Causes \& Control 1993, 4:39-44

37. Kelsey JL, Bernstein L: Epidemiology and prevention of breast cancer. Annu Rev Public Health 1996, 17:47-67

38. Nicholson RI RI: Why ER level may not reflect endocrine responsiveness in breast cancer. Rev End Rel Cancer 1992, 40:252-8

39. Anderson J, Orntoft T, Poulson SH: Semiquantitative oestrogen receptor assay in formalin-fixed paraffin sections of human breast cancer tissue using monoclonal antibodies $\mathrm{Br} J$ Cancer |986, 53:69|-4

40. Snead DJR, Bell JA, Dixon AR: Methodology of immunohistochemical detection of oestrogen receptor in human breast carcinoma in formalin fixed paraffin embedded tissue: a comparison with frozen section morphology. Histopatholy 1993, 23:233-8

41. Goulding H, Pinder S, Cannon P: A new method for the assessment of oestrogen receptor status on routine formalin-fixed tissue samples. Hum Pathol 1995, 26:29|-4

42. King WJ, Greene GL: Monoclonal antibodies localize oestrogen receptor in the nuclei of target cells. Nature 1984, 307:745-47

43. Gaskell DJ, Hawkins RA RA, Tesdale AL: The differing predictive values of oestrogen receptor assays for large breast cancers. Postgrad Med J 1992, 68:900-3

44. Robertson JFR, Bates K, Pearson D: Comparison of two oestrogen receptor assays in the prediction of the clinical course of patients with advanced breast cancer. $\mathrm{Br}$ J Cancer 1992, 65:72730

45. Storm HH: Completeness of cancer registration in Denmark 1943-1966 and efficacy of record linkage procedures. Int J Epidemiol 1988, 17:44-9

46. Fisherman K, Mouridsen HT: Danish Breast Cancer Co-operative Group (DBCG). Acta Chir Scand, Suppl. 1984, 5 I 9:55-59

\section{Pre-publication history}

The pre-publication history for this paper can be accessed here:

http://www.biomedcentral.com/content/backmatter/ 1471-2407-1-8-b1.pdf 